\title{
THE RÔLE OF SOCIAL HEREDITY IN EDUCATION
}

\author{
WALTER ROBINSON SMITH \\ State Normal School, Emporia, Kansas
}

During the last two or three decades we have seen growing up two seemingly irreconcilable attitudes toward heredity. The theory of Weismann that acquired characteristics are not inheritable has been gaining general credence at the same time that eugenics has been formulated into a program. According to the accepted biological point of view acquired traits, either of weakness or strength, disease or health, boorishness or culture, unless they get into the germ plasm, which in general they seem not to do, cannot be perpetuated through organic heredity. According to the eugenic point of view the hope of speedy progress in civilization lies in guarding and guiding the hereditary factors entering into racial development. If the Weismannic dictum that the sort of lives we live has little effect on the organic inheritance we transmit to posterity, then the eugenic program can accomplish little without a more radical change in the processes of parental selection than the hardiest eugenicists have dared seriously to propose. Either the current biological views of heredity must be overthrown, or the eugenic crusaders must confine their hopes to the prevention of only a small, almost negligible, fraction of the most unfit from perpetuating their kind and the stimulus it provides the normal individual to cause him to pay attention to the laws of heredity.

If the eugenic crusade has done little else, however, it has stimulated interest in past achievements and has led to a better recognition of the debt we owe to our ancestors. It has paved the way for what Professor Conn has called "the other side of eugenics," that is, social heredity. If we cannot transmit to our descendants powerful physiques and giant minds, or new instincts, cultivated tastes and sentiments, or a thirst for scientific knowledge, we can at least transmit a social heritage which it is difficult if not impos- 
sible for them to escape. If we are not able to transmit mental and physical constitutions inherently superior to our own, we can transmit an exterior civilization as superior to the one we inherited as our cumulative efforts are able to make it. Any progress made in the arts, in science, in mechanical or economic processes, material contrivances, language, moral codes, government, etc., may be handed on ready-made to the rising generation for its permanent use. The social organism with all its forms and achievements constitutes an inheritance that should guarantee continuous progress, even though we are denied the boon of rapid advance through organic selection.

While the term social heredity has long been used and sociologists have understood something of its significance, it is only recently that attempts have been made to analyze its content and set forth its importance. Professor Conn's illuminating study has cleared the way. He has treated our social inheritance as a body of acquired traits in contradistinction to the natural traits obtained through organic heredity.

The chief factors which separate the European from the Bushman are not, then, in his innate, but in his acquired, characteristics. We do not mean by this that there are no innate differences between the Bushman and the European. The differences in inherited mental power of the two are perhaps great; but the chief differences between them, in adult life, are in the mental powers which each has acquired rather than in the mental attributes which each has inherited. Civilization is thus a heritage, handed down from father to child; but it is like property passed on from generation to generation, and not like that organic inheritance by which the parent transmits to his child the color of his hair, or his eyes, or his stature, or his mental power and moral sense. . . . . Organic heredity has produced the human animal, but social heredity has produced the modern social man. ${ }^{x}$

Professor Conn further contrasts human and animal evolution:

Human evolution has thus been a double one. The laws which had been at work for countless ages producing a world full of its numerous animals and plants produced also the first human animals with some points of strength and some of weakness. But among other features of this new production there were certain instincts that led to social life and to a spirit of self-sacrifice. These new characters in time brought to the front the force of social heredity

${ }^{x} \mathrm{H}$. W. Conn, Social Heredity and Social Evolution, pp. 336, 337. 
and a new era of evolution began, ending in the comparatively rapid evolution of civilization. This latter phase of the great sweep of the evolutionary processes of nature belongs to man alone, and has made him the unquestioned master of nature, the mastery having been given him by his own unique evolution, made possible by the utilization of the new phase of inheritance which has been called Social Heredity. ${ }^{x}$

While Professor Conn has made a valuable contribution to the study of social heredity, he has failed to make any clear distinction between the sociological and the psychological factors entering into it. He has treated the psychological and sociological aspects of man and of civilization indiscriminately. Approaching the subject from the biological standpoint he has accepted every superorganic element as a complex unity and has thus failed to organize his material into definite and usable form. In applying social heredity to education, therefore, it is necessary to get a more specific analysis of the factors concerned with our social heritage than he has given us or than is elsewhere extant.

As the child passes from the hereditary germ plasm to maturity he is shaped and molded mainly by three sets of forces, the organic, the psychic, and the social. The phenomena connected with these forces fall within the three realms of biology, psychology, and sociology. The impact of these forces and the importance of these phenomena vary with the age of the individual. We may say in general that during the prenatal period the dominating forces and phenomena are chiefly organic, during childhood they are largely psychic, and during youth they are pre-eminently social. It cannot be said that psychological and social elements are not concerned with conception, gestation, and birth, for the conditions and controls of all these things are determined to a large extent by the psychic attitudes and reactions of the parents and by social custom, law, economic sustenance, sanitation, and medical science. Neither can we say that the organic and social factors are not prominent in every element of childhood, nor that the biological and psychological factors are not highly important in controlling the youth as he approaches maturity. But in spite of the overlapping of these forces and phenomena there is a progressive trend

H. W. Conn, Social Heredity and Social Evolution, p. 339. 
from the dominance of the physical to the dominance of the social as the human personality evolves.

If we characterize the human qualities derived from each of these forces we might say that through organic heredity we gain the fundamental physical powers, such as the muscular and osseous systems, the nervous system, the vital organs, the germ plasm of reproduction, and such outward features as the color of hair and eyes, skin texture, facial contour, etc. Likewise we inherit a general organic plasticity and adaptability, particularly of the brain, which has slowly increased through the centuries under the laws of selection and survival. Our psychological inheritance consists of a variety of instincts and tendencies and the objective knowledge we possess of human traits, mental qualities and possibilities, moral sentiments and habit controls, the laws of individual growth, the organization of methods of dealing with the child, and the psychological elements entering into the social mechanism. It is psychic activity that connects the individual organism with the social organism, or that directs the individual in his acquisition of the social inheritance. This leaves for our social inheritance the whole static organization of society with its accumulated achievements. To make clear the desired educational applications it is necessary to go into some detail.

Probably the most conspicuous phase of our social inheritance is economic. Our primitive ancestors must have been without the use of fire, tools, weapons, clothing, accumulated stores of food, or knowledge of mechanical processes. Their superiority to the animals with which they were surrounded and with which they had to struggle was mainly a greater mobility and adaptability of physical and mental qualities. Through the application of energy, ingenuity, and forethought they slowly accumulated the store of capital goods which increased their supremacy and paved the way for more rapid production. Tools, weapons, agricultural implements, boats, etc., were invented; houses were built, roads were laid out, clothing was made, food was stored up; animals were tamed and organized into flocks and herds; barter introduced exchange, tools started the handicrafts, and slaves popularized labor. Money developed as a medium of exchange, inventions 
stimulated machinofacture, and credit and business organization were utilized to increase productive capacity. These economic materials and processes have multiplied in number and complexity until each new generation is provided with ready-made mechanical devices, material structures such as houses, ships, roads, factories, bridges, stores of food, clothing, mercantile goods, inventions and labor-saving devices, transportation systems, smooth-running business organizations, etc. All of these things not only tend to establish high standards of life, but are at hand for actual use in elevating the plane of living, and are all but forced upon the rising generation through social agencies.

Scarcely less primitive and basic are the various agencies for stimulating sociability and promoting social intercourse. As the economic system is the outgrowth primarily of the self-sustaining instincts, so the social system is the outgrowth of the aggregative and reproductive instincts. Many of the higher animals have social instincts, and we can hardly conceive of primitive man without impulses to sociability and something of the "consciousness of kind." Under these impulses and instincts our distant ancestors formed a variety of institutions and organizations to encourage social contacts. They developed a complex system of communication made up of gesture, language, and written symbols. The family was instituted and has passed through various stages into the monogamous democratic family group of the present. Religious impulses led to the founding of socially cohesive church groups. The needs of self-protection led to ever-enlarging associations of neighborly clans. Methods of social intercourse settled into customary and fixed channels. Marriage and funeral customs, social conventions, stimulating games, and traditional ceremonies were habitualized. Informal charitable, recreational, fraternal, and cultural associations grew into recognized institutions. As civilization increased in volume and complexity all of these socializing agencies expanded into inchoate or formal organizations for the purpose of conserving and passing on the accumulated social wisdom of the race.

Closely associated with the economic and purely social activities of primitive man were a variety of cultural activities. Folklore 
and mythology laid the foundations of literature in its multitudinous forms. Weird rhythmic chants and the beating of tom-toms paved the way for the complexity, breadth of appeal, and refinement of execution of modern music. Rude decorative devices grew into the painting and sculpture which has left canvasses and statues to inspire the aesthetic idealism of later ages. The savage hut was the forerunner of an architecture which has decked the landscape with ornamental buildings. Oratory, the pageant, and the drama also have primitive origins. The use of crude tools grew into the so-called useful arts, which have ever taken on more and more of the intellectual, emotional, and painstaking qualities of the fine arts. The refinement of the aesthetic sense was closely related to the refinement of the moral sense, and the ethical codes originated in economic and social contacts expanded under cultural stimuli into the chivalry and altruism of later days. All of these things have been gradually socialized and universalized through organization and form the basis for a cultural progress that is cumulative from generation to generation.

Finally, to complete the social inheritance we have the institutions constituting, and under the patronage and control of, governments. Constitutions, local, district, and national governmental organizations, broad police powers and functions, state economic enterprises, and charitable, eleëmosynary, and educational institutions have grown up from crude beginnings and are selfperpetuating. Individual ideas of justice were organized into community customs, customs hardened into fixed laws, and laws were collected into statutory codes. Governmental organization has grown from the spasmodic headship of the war leader to the continuous domination of the centralized modern state, and its functions have expanded from the mere protection of the person to the telic control of numerous individual and institutional activities. With the rise of civilization the political state seems to have quite continuously grown in comparative institutional importance, and internationalism is on the way.

Each of these phases of the social organism, the economic, the social, the cultural, and the governmental, not only provides accumulated materials with which it may impress the rising 
generation, but has definitely constituted agencies for perpetuating itself. All of these means of transmitting the social heritage must be recognized as education. So effective are they that we have learned to expect the environment to dominate almost completely the mental and moral constitution of the individual. The child of a Mohammedan becomes a Mohammedan as naturally and quite as inevitably as he inherits the physical features of his ancestors. No one expects a Jew to be disloyal to the Hebrew religion or to be unmoved by the proud heritage of his race. The Englishman, the Frenchman, or the German must learn to speak his mother-tongue and cannot escape the traditions and customs of his progenitors. Every child absorbs something of his physical and social environment as certainly as he recapitulates the organic evolution of his kind.

Any attempt to organize social heredity as education demands a definite distinction between formal and informal education. Formal education consists of specialized, separate institutions, such as schools, and certain phases of other institutions which are specifically and consciously used for educative purposes. The family constitutes a powerful center of formal, as well as of informal, training. Children are taught in the home to do manual work, such as cooking, sewing, and housekeeping, the use of weapons and tools, farming, gardening, trading, and the foundations of the social amenities and ethical codes. Parts of the church, such as the Sunday-school, classes in church and biblical history, and catechetical drills, are differentiated for teaching purposes. Business and the trades have apprenticeship training, cultural societies have their club papers, fraternal organizations their rituals, and social groups their orderly forms. All these institutions demand the learning of predetermined essentials and in some form teach them line upon line and precept upon precept. In all primitive societies these agencies constituted the only formal education, and they have lost little of their virility in advanced society.

With the advance of civilization, however, they alone were found to be too irregular, uncertain, and ineffective to satisfy the needs of society. The body of social materials grew so complex and social consciousness so acute that it became unwise to intrust so vital a function as education to minor phases of group organiza- 
tions. Social solidarity, social conservation, and social progress became so dependent upon special training that purely educational institutions were differentiated. The dominant institution of the day extended its educative function by founding formal schools which not only embodied its own training materials, but undertook more or less of general education. The Spartan state, the mediaeval church, the local municipality, and the modern centralized government have each established school systems as each in turn conceived its mission to include the guardianship of the social heritage. With the growth of civilization the school as an institution has increased steadily in importance. It has become independent in management, self-conscious in its mission, and instead of being a minor phase of other institutions it is assuming a constructive attitude in determining the functions of other social organizations. In fact, among the advanced nations the school is recognized as the most direct, if not the most powerful, factor in molding individual personality and national ideals.

But the formal education of the schools is largely based upon social heredity. Even so noted an educator as Nicholas Murray Butler has defined education as the acquisition of the cultural inheritance of the race. Most of the language and literature taught comes down from a past age. The scientific textbooks are filled with the facts and principles developed through earlier observation, reasoned premise, and experimentation. History is mainly a record of past civilization, civics an analysis of previous governmental practice, economics a study of business activities up to the present, and sociology an organization of the phenomena and principles gleaned from social evolution and social conditions. Much of the inspiration and materials for teaching the fine arts comes from inherited artistic models. Likewise the institutions for carrying on this teaching have been molded in past ages. School organization, school methods, and school equipment are the result of generations of theorizing, selection by means of trial and error, and cumulative invention. In fact, during most of our educational history the school has been merely a conserving institution, discouraging innovation, and more static than dynamic in its aims and results. Only in advanced societies, more especially in recent years, 
has formal education assumed progressive attitudes or adopted telic programs.

Since formal education has developed an extensive literature of its own, and its function in passing on the social heritage is well understood, we may well confine our efforts to emphasizing the informal aspects of the subject. Informal education consists of the various influences and phenomena which are unconsciously assimilated through mere contact. The child imitates the speech, actions, customs, and habits of his parents. He is taught many lessons as a part of his general control and direction without any thought of their function as education. As a means of mutual understanding and without any consciousness of its value as linguistic training the child is laboriously taught to interpret and use language. $\mathrm{He}$ is aided in gaining bodily co-ordinations, he is stimulated to play, his sense activities are directed, advice is given, moral precepts are iterated, and suggestions are dropped as the rain, with absolute unconsciousness that these things embody the most fundamental educative lessons of life. Self-control, the ability to endure pain, and the importance of struggle and effort are instilled as a corollary of the daily nursery. Certain elements of vocational knowledge, religious practice, political traditions, and racial prejudice are absorbed through family conversation. So great are these early educative influences, mainly within the home, that it has been said that the child passes through the first third of his development before birth and the next third before the close of the fifth year. Likewise it is a Jesuit tradition that the child's religious status may be definitely fixed before he passes his seventh year.

When the child's circle of activity extends beyond the family rooftree another era of unconscious educational progress awaits him. He imitates the language, plays, and customs of his companions, emulates the spirit and attainments of his playmates, and absorbs the knowledge held in solution in his environment. He gets elementary lessons in biology through the observation of plants and animals, and learns something of geography, hygiene, folklore, the fine arts, and mechanical principles through efforts to satisfy his native instinct of curiosity. Building operations, methods of transportation, public utilities such as fire protection and police 
control, mercantile transactions, churches, schools, lodges, and a thousand other physical and social activities fall under his scrutiny. Through tireless activity he increases his physical skill, mental ingenuity, and social adaptability. In short, before the days of formal schooling the child is well started in all the physical, mental, and moral co-ordinations which the educative process demands.

Thus it will be seen that while the primary groups, the home, the playground, and the local community, are not organized for conscious education, they have very large educational functions, both formal and informal. They are the sources of beginnings and have the most plastic period of life in which to make their influences effective. Nor must it be supposed that their educative importance ends with childhood. It extends throughout life, and while the wider social contacts of the intermediate and secondary groups increase in number and significance with advancing age, they must remain extensive in nature as contrasted with the intensive forces of the primary groups. The primary groups continue throughout maturity to form the nuclei around which other associations revolve and face-to-face contacts to determine life's most fundamental choices. Even the selection of a vocation or of a companion in marriage is most likely to be determined by informal primarygroup influences.

In later childhood and youth, however, the larger social groups gain increasing educational importance. The church, the gang, the cultural association, the business, charitable, and political organization, take on new significance. Instead of being an outside observer the boy or girl joins a number of these groups. Each demands loyalty and service and has inchoate or organized methods of enforcing its spirit and will upon the initiate. Within the group social pressure is the dominant factor. It comes down from above through officers and leaders and is exerted laterally by the rank and file of membership. The new member is thus molded into shape and required to assume his share of responsibility for the esprit de corps and work of the group. It is this informal use of group pressure which constitutes the chief educative value of mere organization and group solidarity. It has superior molding power because it unites precept and example, word and deed, learning and doing. 
In many ways the pedagogy of the informal group is superior to the pedagogy of the school.

But if the informal education of such groups as the church, the athletic or social club, the musical, art, dramatic, or literary society, and business and political associations are educative, what shall we say of the informal associations of the school? Between the ages of six and fourteen approximately half of the time of the youth is spent in school, and the school influences extend into other phases of the pupil's life. If the formal education of the youth is continued beyond this period the school becomes even more of a dominating influence in his activities. In our ordinary thinking about the school, however, we overvalue the direct instruction of the teacher, the textbook, the reference library, and the laboratory. School spirit and loyalty, school athletics and playground activities, school organizations for social, cultural, and religious purposes, the extraclassroom contacts of teacher and pupil, and the continual association of the pupil with other pupils possessing different opinions, prejudices, habits, and ideals absorbed from different home environments do much to broaden, deepen, and stimulate the growth of the personality of the impressible adolescent. If these subsidiary influences are not favorable the school can be only partially efficient, regardless of the quality of the classroom teaching or the excellence of the equipment.

The educational value of extra-curricular influences in school life will be made apparent by a detailed study of any particular school system, or by an analysis of the opinions of the alumni of any famous school concerning the factors which had the greatest influence in molding their characters. Everyone is familiar with the traditional influence of the great English public schools upon their graduates. Wellington's oft-quoted statement that Waterloo was won on the cricket fields of England is paralleled by hundreds of references to the dominating nature of "school life" in shaping the lives of great men. Graduates of our best academies and colleges seldom refer to what they learned, but to what they grew into in the atmosphere of their Alma Maters. Talent for organization, the will to succeed, breadth of sympathy, understanding of human nature, social adaptability, the joy of human struggle, the 
instinct and practice of leadership, and a wide variety of personal qualities and ideals come not from the classroom, but from the athletic field, the dormitory, the club, the fraternity, the literary society, the school paper, the Young Men's Christian Association, the debating league, school politics, and social gatherings. In fact, if we take their word at face value, most men of character and influence owe their success to "college life" rather than to their college studies.

Moreover, just here lies the greatest weakness of the American public schools as compared with the best private schools. They are generally lacking in traditions, school organization, and esprit de corps. Public-school teachers are as fully trained, are more specifically trained, and are not inferior in personality to teachers in private schools of the same grade. Nor are public-school buildings and equipment inferior. But they do lack something in the traditional molds for habit formation and the selective organization for stimulating chosen ideals found in such old preparatory schools as Exeter, Andover, Groton, and St. Paul's. . With increasing age and an enlarged alumni, with the rise of athletics, with playground and music supervisors, and with wisely sponsored literary, art, religious, and social organizations something of the same cultural traditions and ideals may be fostered. Alongside this increased social pressure the democratic stimulus of undifferentiated social classes, the tolerance bred of clashing ideals, and the socializing effect of widely differing vocational and philanthropic ambitions should still persist. Likewise the telic breadth of state vision should demand and provide a wider range of opportunities for educational selection than could be expected in a private school. It is the mixing of cultures in the crucible of democratic school groups that inspires confidence in the future of the public school.

A not less illuminating method of getting at the value of the informal education of social heredity might be made by tracing the origin of our specific ideals. Whence come our patriotism, our party allegiance, our religious predilections, our business standards, our sex chivalry, our social etiquette and savoir faire, our selfcontrol, our co-operative spirit, and our altruism? Where do we get our taste in food, clothing, furniture, and houses, our sex 
knowledge, our occupational and marital choices, our chums and our amusements? Certainly most of these things are not determined by any formal instruction, but are breathed in through the social atmosphere of our native environments. To what extent has the teaching of civics aided in driving out the political bosses or in eliminating grafters? How many men have changed their party alignments as a result of the teaching of government in our schools? How much more patriotic, or chivalrous, or altruistic are our college graduates than our ordinary citizens? As a matter of fact party affiliations are usually formulated in the home, confirmed in playground squabbles, and sealed in the party caucus. Church membership is ordinarily decided before the age of discretion without any element of judgment based upon knowledge entering into the situation. Social etiquette and our general tastes are copied from the home or the larger community environment. Our sex knowledge is picked up on the streets or in stealthy conferences with the more or less depraved. Our chums and amusements are selected from local associations, and our standards of business honor and of workmanship are fixed quite largely by our occupational associations.

Taken as a whole, it would be safe to say that in all relations in life where feeling reactions are more important than intellectual decisions the unconscious education of the folkways, traditions, conventions, customs, and organized institutions of society gained through informal contacts with our fellows and our environment has more influence in molding our characters and determining our destiny than has formal education. This holds true for all classes but more particularly for the masses whose school days are limited. It would not do to overlook the fact that organized education tends to enable us to control our feelings, that it adds refinement to our sentiments and strengthens our characters; but likewise it would not serve the truth to overlook the fact that much of our most useful knowledge, much that enters into our best judgments, is acquired through informal and haphazard contacts. The truth seems to be that as civilization advances formal education increases its reach and power over the social heritage, but as yet we have not attained, for the masses of the people at least, a stage where we can 
expect the selected materials of the schools to be as dominating over our society as are the heterogeneous materials of unconsciously propagated social heredity. Much can be done to improve presentday materials and methods, but the day is far distant when we can persuade the boy to give up his street vernacular for the language of the textbook, to read only the type of literature found in the school library, to produce and listen only to the music selected for school use, to eat the food, wear the clothes, adopt the habits, and live the ideals suggested by his teachers. In the meantime he will inherit from his social environment a large share of his personal characteristics as unconsciously as he inherits the physical traits of his ancestors.

Generalizing the analysis of the preceding pages, it is to nurture rather than nature, to environment rather than organic heredity, that we must look mainly for social progress. Even such studies of degeneracy as that of the Jukes family, or of genius as shown in the Edwards family, or the vast array of materials collected by the eugenicists fail to be convincing when it is remembered that the children of these families grew up under the educative conditions surrounding their homes. It may be impossible to develop a genius out of an ordinary individual or a good citizen out of a born criminal by providing a favorable educational environment; but it is equally impossible to develop a genius without affording him opportunities, or a good citizen where there is no reward for virtue. Professor Ward may have overstated the case when he asserted that genius inheres in all classes of society almost equally, but he certainly did not overemphasize his thesis when he elaborated the rôle of opportunity in human progress. When such a preponderating number of great actions grow out of great occasions, when a man born in Paris has thirty times the chance of greatness of one born in rural France, when from two to four times their relative proportions of our own leaders are born in our larger cities, and when such an enormous percentage of our criminals come from vicious environments, it is scarcely necessary to assume that one's doom is sealed by his unwitting choice of ancestors.

Moreover, granting the influence of organic heredity claimed by the eugenicists, they have comparatively little to offer in the way of 
stimulating progress They do not show how, by taking thought, we can greatly improve the organic heritage of our descendants. On the other hand, we can consciously and deliberately improve the social heritage we expect to transmit. Since mere physical features, such as climate and topography, exercise increasingly less influence over us, we can very largely control our environment artificially. With each new age we pile up additional economic, cultural, and institutional treasures for the use of posterity. We have the privilege, even the duty, of making over our social, religious, political, and educational systems to provide greater safeguards and more effective media for the training of the young. While the telic programs outlined to improve organic heredity touch vitally only the few, mainly the abnormal, the telic programs for improving social heredity are equally vital for all. In other words, the laws of organic heredity are biological and hence beyond psychic control, while the laws of social heredity fall within the province of psychic direction and form the basis of the great educative scheme to guarantee social progress through improving social conditions. 